\title{
PENGARUH TERAPI OKUPASI TERHADAP GEJALA HALUSINASI PENDENGARAN PADA PASIEN HALUSINASI PENDENGARAN RAWAT INAP DI YAYASAN AULIA RAHMA KEMILING BANDAR LAMPUNG
}

\author{
Niken Yuniar Sari, Budi Antoro, Niluh Gede Pita Setevani \\ Universitas Mitra Indonesia, Bandar Lampung \\ E-mail: nikenyuniar@umitra.ac.id
}

\begin{abstract}
ABSTRAK
Halusinasi adalah pengalaman atau respon yang salah terhadap stimulasi sensorik. Salah satu penatalaksanaan halusinasi adalah terapi okupasi. Penelitian ini bertujuan untuk mengetahui distribusi frekuensi gejala halusinasi pendengaran pada pasien halusinasi pendengaran. Menggunakan desain quasi wxperiment pre-post test without control group. Sejumlah 27 sampel dipilih dengan teknik total sampling, instrument yang valid dan reliabel. Analisis menggunakan dependent t test. Hasil penelitian menunjukan gejala halusinasi menurun setelah diberikan terapi okupasi. ( $p$-value $<\alpha 0,05)$, frekuensi gejala halusinasi pendengaran yang dialami klien halusinasi pendengaran sebelum diberikan terapi okupasi yang paling banyak dalam katagori sedang (51,9\%). Setelah diberikan terapi okupasi gejala halusinasi pendengaran yang paling banyak dalam katagori ringan $(44,4 \%)$ Terapi okupasi di rekomendasikan untuk mengatasi halusinasi pada klien halusinasi pendengaran.
\end{abstract}

Kata Kunci : Halusinasi Pendengaran, Terapi Okupasi,

\begin{abstract}
Hallucinations are an experience of one or the wrong response to sensory stimulation. One of the management of hospitals with hallucinations is occupational therapy.This study aims to determine the frequency distribution of auditory hallucinatory symptoms in auditory hallucinatory patients. Using the quasi experiment pre-post test without control group design. A total of 27 samples were selected by total sampling technique, a valid and reliable instrument. The analysis uses dependent t test. The results showed hallucinations symptoms decreased after being given occupational therapy. ( $p$-value $<\alpha$ 0.05), the frequency of auditory hallucinations symptoms experienced by auditory hallucinations clients before being given the most occupational therapy in the medium category (51.9\%). After being given the most auditory hallucinations symptom therapy in the mild category (44.4\%) Occupational therapy is recommended to treat hallucinations in clients with auditory hallucinations.
\end{abstract}

Key Words: Hearing Hallucinations, Occupational Therapy 


\section{PENDAHULUAN}

Penderita gangguan jiwa didunia diperkirakan akan semakin meningkat seiring dengan kemajuan kehidupan masyarakat. Hampir 400 juta penduduk dunia menderita masalah gangguan jiwa, diantaranya skizofrenia yang merupakan gangguan jiwa berat atau kronis, saat ini diperkirakan 26 juta orang didunia akan mengalami skizofrenia, mengatakan lebih dari $90 \%$ pasien dengan skizofrenia mengalami halusinasi, dan halusinasi yang sering terjadi adalah halusiansi pendengaran, pengelihatan, halusinasi penciuman dan pengecapan (Yosep, 2009).

World Health Organization (WHO, 2013) menyatakan setidaknya ada satu dari empat orang didunia mengalami masalah mental, dan masalah gangguan kesehatan jiwa yang ada diseluruh dunia sudah menjadi masalah yang serius.Dimana terdapat sekitar 35 juta orang terkena depresi, 60 juta terkena bipolar, 21 juta terkena skizofrenia, serta 47,5 juta terkena dimensi.

Departemen Kesehatan Republik Indonesia (Depkes) pada tahun 2014 menyatakan jumlah gangguan jiwa di Indonesia mencapai angka 2,5 juta dari 150 juta populasi orang dewasa di Indonesia, dan terdapat 1,74 juta orang mengalami gangguan mental emosional. Di Indonesia, jumlah penderita gangguan jiwa berat (psikosis/skizofrenia) adalah 1,7 perseribu penduduk.Rumah Sakit Jiwa Diindonesia menyatakan sekitar $70 \%$ halusinasi yang dialami oleh pasien gangguan jiwa adalah halusinasi pendengaran, 20\% halusinasi pengelihatan, dan $10 \%$ adalah halusinasi penciuman, pengecapan dan perabaan.

Data Rumah Sakit Jiwa Provinsi Lampung tahun 2013 jumlah penderita gangguan jiwa sebanyak 15.720 orang dan sebanyak 7.422 orang $(47,2 \%)$ mengalami skizofrenia dan penderita gangguan jiwa meningkat ditahun 2014 menjadi 17.528 orang dan sebesar 8850 orang $(50,7 \%)$ mengalami skizofrenia (Rekam Medik RSJ Provinsi Lampung, 2014).

Berdasarkan data yang diperoleh di Yayasan Aulia Rahma, Kemiling, Bandar Lampung Tahun 2018 jumlah penderita halusinasi hingga akhir februari 2018 tercatat kasus tertinggi dengan pasien halusinasi terdapat 49 pasien penderita halusinasi dari 70 pasien yang dirawat diklinik tersebut. Diantaranya terdapat 27 pasien dengan halusinasi pendengaran, 12 pasien dengan halusinasi penglihatan, 7 pasien dengan halusinasi perabaan dan 3 pasien dengan halusinasi penciuman.

Halusinasi adalah sebagai pengalaman yang salah atau persepsi yang salah atau respon yang salah terhadap stimulasi sensorik.Suatu penyimpangan persepsi palsu yang terjadi pada respon neurologis maladatif.Seseorang sebenarnya mengalami penyimpangan sensorik sebagai hal yang nyata dan 
meresponya. Halusinasi dapat muncul dari salah satu panca indra (Stuart, 2013). Respon terhadap halusinasi dapat mendengar suara, curiga, khawatir, tidak mampu mengambil keputusan, tidak dapat membedakan nyata dan tidak nyata.Pasien halusinasi disebabkan karena faktor pola asuh, perkembangan, neurobiology, psikologis sehingga menimbulkan gejala halusinasi. Seseorang yang mengalami halusinasi bicara sendiri, senyum sendiri, tertawa sendiri, menarik diri darin orang lain, tidak dapat membedakan nyata dan tidak nyata (Stuart, 2013).

Penatalaksanaan pasien dengan halusinasi ada beberapa seperti farmakoterapi, terapi kejang listrik, psikoterapi dan rehabilitas yang diantaranya terapi okupasi, terapi sosial, TAK, terapi lingkungan (Prabowo, 2014). Penelitian I Wayan Candra dkk (2013) meneliti terapi okupasi aktivitas menggambar terhadap perubahan halusinasi pada pasien skizofrenia hasil penelitian menunjukan $\mathrm{p}=0,000$. Hasil tersebut menemukan adanya pengaruh terapi okupasi aktivitas menggambar terhadap perubahan halusinasi pada pasien skizofrenia.

Aktivitas menanam yang dilakukan bertujuan untuk meminimalisasi interaksi pasien dengan dunianya yang tidak nyata, mengeluarkan pikiran, perasaan, atau emosi yang selama ini mempengaruhi perilaku yang tidak disadarinya, memberi motivasi dan memberikan kegembiraan, hiburan, serta mengalihkan perhatian pasien dari halusinasi yang dialami sehingga pikiran pasien tidak terfokus dengan halusinasinya khusus nya pada pasien halusinasi pendengaran (Yosep, 2009).

Tujuan penelitian ini adalah Mengetahui Pengaruh Terapi Okupasi Terhadap Gejala Halusinasi Pendengaran Pada Pasien Halusinasi Pendengaran Rawat Inap Di Yayasan Aulia Rahma, Kemiling Bandar Lampung Tahun 2018.

\section{METODOLOGI}

Penelitian ini menggunakan jenis penelitian kuantitatif, menggunakan design eksperimen dengan rancangan penelitian preksperiment dengan pendekatan one group pretest-postest design. Populasi dalam penelitian ini adalah seluruh pasien halusinasi pendengaran di Yayasan Aulia Rahma, Kemiling Bandar Lampung dengan jumlah 27 pasien halusinasi pendengaran. Sampel yang digunakan pada penelitian ini adalah total sampel adalah 27 pasien dengan halusinasi pendengaran. penelitian ini adalah Teknik Total Sampling.

Langkah-langkah pelaksanaan penelitian Pretest dilakukan dengan cara melakukan observasi gejala halusinasi pendengaran kepada responden menggunakan lembar observasi yang diobservasi adalah isi halusinasi, frekuesnsi halusinasi, situasi pencetus, dan respon pasien. 
Setelah melakukan selesai pretest, selanjutnya melakukan terapi pada hari berikutnya yang dimana akan dilakukan 1-2 jam dengan beberapa tahap, tahap 1 dengan waktu 1/2-1 jam terdiri dari tahap persiapan dan orientasi, melakukan persiapan alat-alat dan bahan seperti menyiapkan tanaman, sekop, polibag, pupuk, air,dll setelah itu tahap kedua 1-1/2 yang terdiri dari tahap kerja dan tahap evaluasi, dimana pada tahap ini ajarkan responden bagaimana cara menanam dan merawatnya, saat menanam yang pertama dilakukan adalah menggali tanah yang akan digunakan, setelah itu memberikan contoh untuk pertama kali kepada responden dalam menanam sayuran.

Setelah evaluasi, jika sudah melakukan terapi lakukan evaluasi dengan cara menanyakan kepada responden apakah responden senang melakukan menanam sayuran dan memberikan hadiah kepada responden yang sudah mau dalam mengikuti terapi sebagai penghargaan kepada partisipan, setelah evaluasi peneliti melakukan kontrak waktu kepada partisipan dan wali responden untuk terapi selanjutnya terapi yang akan dilakukan selama 2 minggu dengan 1 minggu dilakukan 3 sesi pertemuan, sehingga terdapat 6 sesi pertemuan untuk 2 minggu. Pada hari ke 15 dilakukan observasi (Posttest) untuk mengukur gejala halusinasi pendengaran. Instrument pengumpulan data yang digunakan Pre Testdan Post Testberupa lembar observasi untuk mengukur gejala halusinasi pendengaran berdasarkan lembar observasi yang sudah baku. Instrument ini terdiri dari karakteristik responden, dan gejala halusinasi.Teknik analisa data yang digunakan dalam penelitian ini adalah uji Wilxocon Sign Rank Test.

\section{HASIL}

Karakteristik responden penelitian ini akan dijelaskan seperti usia, jenis kelamin, lama dirawat, dan pekerjaan

Tabel 1. Karakeristik Berdasarkan Usia

\begin{tabular}{|c|c|c|}
\hline Umur & Frekuensi & $\begin{array}{c}\text { Persentas } \\
\text { e }\end{array}$ \\
\hline$<21$ tahun & $\underline{0}$ & $0 \%$ \\
\hline 21-40 tahun & 19 & $70,4 \%$ \\
\hline $40-60$ tahun & 8 & $29,6 \%$ \\
\hline$>60$ tahun & 0 & $0 \%$ \\
\hline Total & $\underline{27}$ & $100 \%$ \\
\hline
\end{tabular}

Tabel 1. dapat diketahui bahwa distribusi frekuensi usia pada responden halusinasi pendengaran paling banyak pada katagori usia 21-40 tahun dengan jumlah 19 responden dengan persentase $70,4 \%$. Menurut peneliti pada tahap ini responden berusaha membuktikan dirinya sebagai seorang pribadi dewasa dan mandiri. 
Tabel 2. Karakteristik Berdasarkan Jenis Kelamin, Lama Dirawat Dan Pekerjaan

\begin{tabular}{|c|c|c|c|}
\hline No & Karakteristik & $\mathbf{F}$ & $\%$ \\
\hline \multicolumn{4}{|c|}{ 1. Jenis kelamin } \\
\hline & \multirow{2}{*}{$\begin{array}{ll}\text { a. } & \text { Laki-laki } \\
\text { b. } & \text { Perempua } \\
& n\end{array}$} & 20 & $74,1 \%$ \\
\hline & & 7 & $25,9 \%$ \\
\hline
\end{tabular}

2. Lama di rawat

\begin{tabular}{clcc}
\hline a. & $1-5$ tahun & 14 & $51 \%$ \\
\hline b. & $\begin{array}{l}6-10 \\
\text { tahun }\end{array}$ & 13 & $48,1 \%$
\end{tabular}

3. Pekerjaan

\begin{tabular}{rlcc} 
a. & Pedagang & 8 & $29,6 \%$ \\
\hline b. & Petani & 10 & $37,0 \%$ \\
\hline c. & $\begin{array}{l}\text { Wiraswas } \\
\text { ta }\end{array}$ & 2 & $7,4 \%$ \\
d. & IRT & 6 & $22,2 \%$ \\
\hline e. & Supir & 1 & $3,7 \%$ \\
\hline
\end{tabular}

Tabel 2.dapat diketahui bahwa distribusi frekuensi karakteristik pada responden seperti jenis kelamin, lama sakit, dan pekerjaan responden. Frekuensi jenis kelamin pada klien halusinasi pendengaran paling banyak pada katagori jenis kelamin laki-laki dengan jumlah 20 responden dengan persentase $74,1 \%$, frekuensi lama sakit pada klien halusinasi pendengaran paling banyak pada katagori lama sakit 1-5 tahun dengan jumlah 14 responden dengan persentase $51,9 \%$, dan frekuensi pekerjaan pada klien halusinasi pendengaran paling banyak pada katagori pekerjaan petani dengan jumlah 10 responden dengan persentase $37,0 \%$.

Tabel 3. Distribusi Frekuensi Gejala Halusinasi Pre-Test

\begin{tabular}{ccc}
\hline $\begin{array}{c}\text { Gejala Halusinasi } \\
\text { Pendengaran (Pre-Test) }\end{array}$ & F & \% \\
\hline Berat & 13 & $48,1 \%$ \\
Sedang & 14 & $51,9 \%$ \\
Ringan & 0 & $0 \%$ \\
Total & $\mathbf{2 7}$ & $\mathbf{1 0 0 \%}$ \\
\hline
\end{tabular}

Tabel 3 menunjukan gejala halusinasi pendengaran klien halusinasi pendengaran sebelum diberikan terapi okupasi paling banyak dalam kategori sedang dengan jumlah responden 14 responden dengan persentase $51,9 \%$.Hasil penelitian ini sesuai dengan penelitian yang dilakukan oleh I Wayan Candra Dkk (2013) yang meneliti tentang terapi okupasi terhadap aktivitas menggambar terhadap perubahan halusinasi pada pasien skizofrenia. Hasil penelitian menemukan bahwa sebelum diberikan terapi okupasi aktivitas menggambar sebagaian besar yaitu 15 orang $(50,0 \%)$ mengalami halusinasi tingkat sedang.

Hasil penelitian yang didapat menunjukan sebelum diberikan terapi okupasi aktivitas menanam gajala halusinasi pendengaran yang dialami pasien halusinasi pendengaran sebagaian besar berada dalam kategori sedang. Hal ini disebabkan karena halusinasi pendengaran menyebabkan pasien mengalami ketidakmampuan atau kerusakan dalam hubungan sosialnya sehingga pasien hidup dialamnya sendiri, berinteraksi dengan pikirannya yang diciptakan sendiri, seolaholah semuanya menjadi sesuau yang nyata sehingga responden tidak dapat mengalihkan dan mengontrol halusinasi yang dialaminya.

Pasien yang sehat mampu mengidentifikasi dan menginterprestasikan stimulasi berdasarkan informasi yang diterima melalui panca indra, pasien dengan halusinasi 
mempersepsikan suau stimulasi dengan panca indra yang sebenarnya stimulus tersebut tidak ada.

Menurut Muhith (2015) mengatakan halusinasi dibagi menjadi intensitas halusinasi dalam 4 bagian berdasarkan tingkat ansietasnya yang dialami dan kemampuan klien dalam mengendalikan dirinya.

Tabel 4. Distribusi Frekuensi Gejala Halusinasi Pendengaran Post-Test

\begin{tabular}{ccc}
\hline $\begin{array}{c}\text { Gejala Halusinasi } \\
\text { Pendengaran (Post- } \\
\text { Test) }\end{array}$ & F & \% \\
\hline Berat & 5 & $18,5 \%$ \\
Sedang & 10 & $37,0 \%$ \\
Ringan & 12 & $44.4 \%$ \\
Total & $\mathbf{2 7}$ & $\mathbf{1 0 0 \%}$ \\
\hline
\end{tabular}

Tabel 4. gejala halusinasi pendengaran pada klien halusinasi pendengaran setelah diberikan terapi okupasi paling banyak dalam kategori ringan dengan jumlah responden 12 responden dengan persentase 44,4\%. Hasil penelitian ini sesuai dengan I Wayan Candra Dkk (2013) hasil penelitian ditemukan bahwa seelah diberikan terapi okupasi aktivitas menggambar sebagian besar yaitu ringan dengan 21 responden $(70,0 \%)$ mengalami penurunan.

Hasil penelitian dari uji satistik didapatkan Hasil Uji Wilcoxon didapat P Value $0,00<$ 0,05 , artinya ada pengaruh terapi okupasi terhadap gejala halusinasi pendengaran pada pasien halusinasi pendengaran rawat inap di
Yayasan Aulia Rahma Kemiling, Bandar Lampung Tahun 2018. Hasil penelitian ini sesuai dengan penelitian yang dilakukan oleh Ni Made Wijayanti Dkk (2012) terapi okupasi aktivitas waktu luang terhadap perubahan gejala halusinasi pendengaran pada pasien skizofrenia dengan hasil $\mathrm{p}=0,000$ yang berati ada pengaruh terapi okupasi aktivias waktu luang terhadap gejala halusinasi pendengaran pada pasien skizofrenia. Hasil penelitian lainnya I Wayan Candra Dkk (2013) terapi okupasi aktivitas menggambar terhadap perubahan halusinasi pada pasien skizofrenia dengan hasil $\mathrm{p}=0,000$.

\section{PEMBAHASAN}

Hasil penelitian menunjukan sebagian besar gejala halusinasi pendengaran pada klien halusinasi pendengaran setelah diberikan terapi okupasi paling banyak dalam kategori ringan dengan jumlah responden 12 responden dengan persentase $44,4 \%$. Terjadi penurunan gejala halusinasi pendengaran setelah diberikan erapi okupasi karena pada saat pelaksanaan terapi okupasi dapat meminimalisasi interaksi pasien dengan dunianya sendiri, mengeluarkan pikiran, perasaan, atau emosi yang selama ini mempengaruhi perilaku yang tidak disadarinya, memberi motivasi dan memberikan kegembiraan, hiburan, serta mengalihkan perhatian pasien dari halusinasi yang dialami sehingga pikiran pasien tidak terfokus dengan halusinasinya khusus nya 
pada pasien halusinasi pendengaran. Dimana banyak penelitian yang sudah membuktikan bahwa terapi okupasi dapat mengubah gejala halusinasi pendengaran.

Terjadi penurunan gejala halusinasi pendengaran yang mengalami setelah diberikan terapi okupasi, karena pasien mampu melakukan aktivitas dengan baik pada saat pelaksanaan terapi. Keadaan demikian mempengaruhinpasien lain tetap focus dan menikmati aktivias yang diberikan untuk mengikuti teman sekelompoknya sehingga halusinasi dapat dialihkan. Hal ini sesuai dengan Herman (2011) Aktivitas dalam okupasi terapi hanya media, tidak untuk menyembuhkan. Peranan terapi tersebut sebagai penghubung antara batin klien dengan dunia luar, berhubungan dengan tujuan pekerjaan dan dapat meningkatan kemampuan klien bersosialisasi dalam kelompok terapi.

Diamati dan dicermati satu persatu dari seluruh responden penelitian ditemukan ada 2 responden gejala halusinasi pendengarannya hanya menurun sedikit sebelum dan sesudah diberikan terapi okupasi.Keadaan ini dapat terjadi karena pasien belum mampu mengalihkan dan mengontrol halusinasi yang dialaminya.

Begitu besarnya pengaruh terapi okupasi terhadap gejala halusinasi, diharapkan petugas kesehatan dapat lebih meningkatkan intevensi terapi okupasi dengan terlebih dahulu melakukan pengkajian tentang : No. 2615-8604 tentang gangguan persepsi sensori: halusinaisi pada klien, kemudian menentukan masalah atau diagnosa keperawatan yang muncul, menyusun rencana tindakan keperawatan terapi okupasi, melakukan implementasi dan evaluasi sehingga gejala halusinasi pendengaran dapat menurun.

\section{KESIMPULAN}

Karakterisik klien dengan gejala halusinasi pendengaran paling banyak pada usia 21-40 tahun, lalu jenis kelamin pada klien halusinasi pendengaran paling banyak dengan jenis kelamin laki-laki, untuk frekuensi lama dirawat paling banyak pada 1-5 tahun, dan untuk pekerjaan klien paling banyak pada pekerjaan petani.

Distribusi frekuensi gejala halusinasi pendengaran pada pasien halusinasi pendengaran sebelum diberikan terapi okupasi lebih tinggi dalam kategori sedang dengan jumlah 14 responden dan distribusi frekuensi gejala halusinasi pendengaran pada pasien halusinasi pendengaran setelah diberikan terapi okupasi lebih tinggi dalam kategori ringan dengan jumlah 12 responden.

Hasil menunjukan ada pengaruh terapi okupasi terhadap gejala halusinasi pendengaran pada pasien halusinasi pendengaran rawat inap Di Yayasan Aulia 
Rahma, Kemiling, Bandar Lampung Tahun

2018.

\section{KEPUSTAKAAN}

Departemen Kesehatan Indonesia, (2014).www.depkes.go.id diakses 10 maret 2018.

Herman (2011). Buku Ajar Asuhan Keperawatan Jiwa:Yogyakarta: Noha Medika, 2011.

I Wayan Chandra \& Ni Kadek Rikayanti, (2013).Pengaru terapi okupasi aktivitas menggambar terhadap perubahan halusinasipada pasien skizofrenia. Susana dan Hendarsih, 2011. www.poltekes-denpasar.ac.id diakses 6 maret 2018.

Yosep. I (2009) Keperawatan Jiwa, Refika Editama, Bandung

Kementrian Kesehatan Lampung, (2013). https://dinkes.lampungprov.go.id diakses 6 maret 2018.

Muhith, Abdul. (2015). Pendidikan Keperawatan Jiwa: Yogyakarta.Andi,2015.

Ni Made Wijayanti, I Wayan Candra \&I Dewa Made Ruspawan, (2012). Terapi Okupasi Aktivitas Waktu Luang Terhadap Perubahan Gejala Halusinasi Pendengaran Pada Pasien Skizofrenia. www.poltekkes-denpasar.ac.id. Diakses 6 maret 2018.

Prabowo, Eko. (2014). Konsep \& Aplikasi Asuhan Keperawatan Jiwa:Yogyakarta: Nuha Medika, 2014

Rekam Medik (2014) Rumah Sakit Jiwa Daerah Provinsi Lampung

Stuart, Gail W. (2013). Prinsip Dan Praktik Keperawatan Kesehatan Stuart, 1 St Indonesia Edition, By Budi Anna Keliat And Jesica Pasaribu:Copyright (C) 2016 Elsevier Singapore Pte Ltd.

World health organization (2013) mental disorder.www.who.int diakses 24 maret 2018. 